\title{
The Evaluation of Study Success between Online Study and Classroom Study Environment
}

\author{
Phudinan Singkhamfu \\ College of Arts, Media, and Technology. Chiang Mai University, Chiangmai, 50200, Thailand
}

\begin{abstract}
Online study has increasingly become more attractive to students at university level due to convenience access to their instructors and to study resources. This study has developed online social network for study. It proposes to provide lesson content availability, past lecture, by sending online study lesson media to students' mobile phone or tablet. Approximately 85 undergraduate software engineering students participated for 1.5 semesters. In comparing the use of the study toll, and without the tool, the alterations were found between traditional classroom learning style and online study. Also, the study's aim was to attest the online study tool's efficiency. However, these results were not obvious when the achievement factor was controlled by the limitation of time. The primary purpose of this study is to evaluate these two groups of students with extended experiment time for a noticeable result by used questionnaires course examination, and inventory of ILP learning process. The observed, shows that students with online study tools scored higher on course examinations after measures by the mentioned methodology.
\end{abstract}

\section{Introduction}

In many ways, when accessed, computer technology greatly benefits students. Also the application allows for students to have convenient access to access to their instructors, as well as present course content. What was examined is the possibility that computer technology may assist students study skills more effectively. While the previous part of this research made use of study tools developed especially for this project, many introductory textbooks now provide students the option of accessing web sites and online study content. Resources such as these intend to help students master text book context and may be viewed as alternatives to the more traditional student study guide. Using computing tools, instructors can assist in preparing study experiences for students. They are made available and are sometimes offered at no extra cost from textbook publishing companies.

We have taken note a percentage of Thai students tend to ignore long texts found in books or long paragraphs which correspond to the content of theirs. The trend of social network communication is significantly popular among university students. We observe that short texts were viewed more frequently long texts. Facebook status is a god example; users regularly update what are they doing or have done. The message comes as a short message and every sender's friends are happy to read the status or post shared.

The concept of the software is that students would be motived to read abridged lesson content. An exploratory observation shows that students always use their mobile phones to frequently access their Facebook page when free. Post classroom learning processes can be adopted by simulating the Facebook status and replaced by shot lesson messages, then simultaneously sending out student peers the post to be shared.

Classroom interaction is reported to create benefits in relation to the rise of more active learning environments, the learning communities can base on application interface that represents a social network application, and the provision of greater feedback for lecturers. Also, it accelerates student motivation. However, using this application to conduct an interactive class is not an easy exercise in perspective. Lecturers may feel that classes are more interactive because they ask questions or accept questions, but they frequently fail to inspect the quality, content, frequency or length of each interaction, in addition to the number of participating students. Thoughts project aims to reduce the gap between in classroom and after class room activity, the lecturer can initiate interactivity after class by using short messages as is done on Facebook status to remind students of the in class lesson content. Students who already have seen the posted message will be able to pass "Impressed" and "Comment" on each single message, while the other students will receive notifications which other students have shared.

\section{Methodology}

Various designations of interactivity exist in the literature, which focus on the in classroom participation and technology Moore defines key interactions as learner- 
content, learner-instructor, and learner-learner [1]. Also there are different ways in defining interactivity aimed to the structure regarding loops rationality and originator. Yacci define the interactivity as a message loop, which is commenced and concluded by the student also the message content must be "mutually coherent" [2]. Earlier definitions developed from communication and educational theories are technology independent.

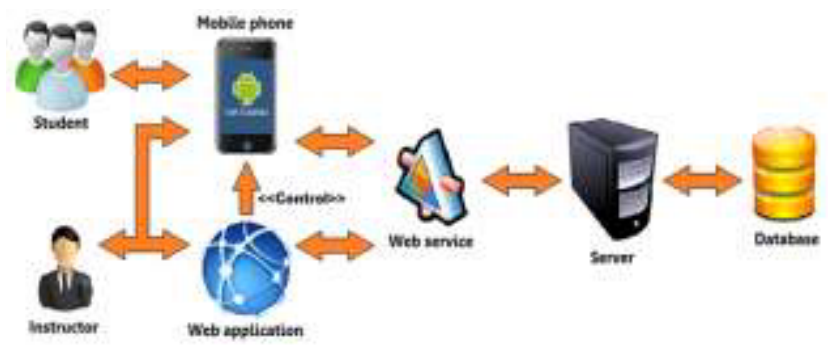

Figure 1. The system architecture of the application.

The applications were designed to enhance student enthusiasm and study success: By accessing instructor posts. With the available feature to criticize and leave comments, the students can interact with their peers or with the class instructor without interrupting as would be the case in class activities, [3]-[4] Fig 1. Students and Instructor are concern as the main focus of this design; the mobile application is ICT interface for students to make any in class and after class interaction, as well as for instructor use. The web application is a tool for instructor the application's aim is to make lesson plans and post them via the mobile application which provides students accessibility to this information. The application enables any instructor to create lesson submitting schedules as automatic submission or real time posting. Both sections provide the notification feature. Real time availability via one's mobile phone aims to increase the student's motivation to study [5]. One feature of the web application is that students are able to receive a join request from class peers. The web application creates a new class by instructors. Concerning classes, instructors can post their lesson content into the mobile application [6].

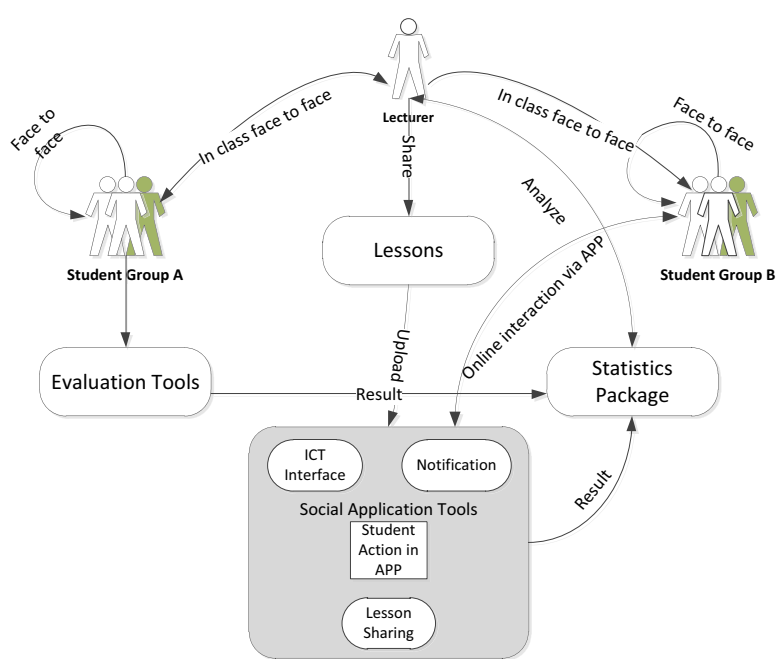

Figure 2. Information flow of the proposed analysis tools, as related to the lecturer, student group A and student group B

The Fig 2. Shows work flow of this research and relation of lecturer, student group A, and student group B. According to the figure only student group $\mathrm{B}$ in online access to the online application. In the other hand, student group $\mathrm{A}$ is maintaining the ordinary teaching style by face to face study with lecturer in class. Firstly, lecturer uploads scheduled short message lesson for student group $\mathrm{B}$ by use the social application tools [6]-[7]. There are similarities between both study group are both them also attend the lecture class and meet lecturer face to face, and they also have change to interaction with each other face to face in class room.

Fig. 3 Illustrated action flow of application, the first step begins as the lecturer utilizes the web application to create a short lesson message by posting, in real time or schedule to post at the pre-set time. The post sent to the mobile application while notifying students via their phones that the latest lesson detail has been sent. Students may only view newer all old lesson content through use of the mobile application. As such, students can click "Impressed" which works similarly to "LIKE" on Facebook, the "Impressed" function will also generate notifications to be sent to other student-peers, drawing attention to specific unread messages. 


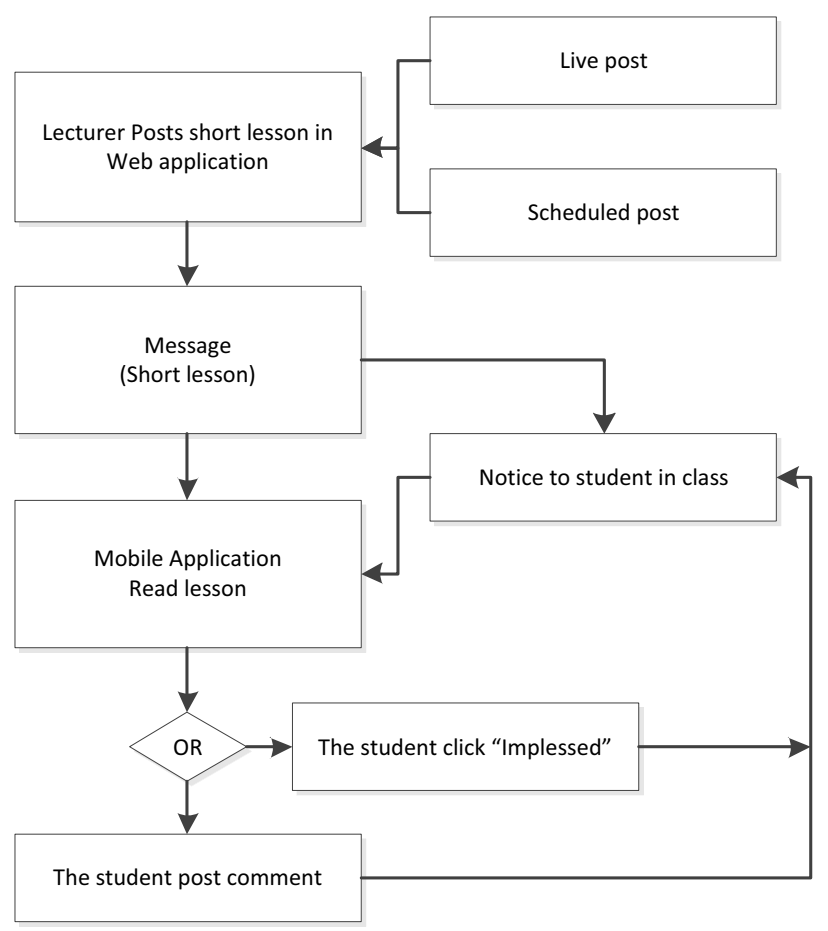

Figure 3. Flow of the social application tools [6].

Figures and tables, as originals of good quality and well contrasted, are to be in their final form, ready for reproduction, pasted in the appropriate place in the text. Try to ensure that the size of the text in your figures is approximately the same size as the main text (10 point). Try to ensure that lines are no thinner than 0.25 point.

On top of this, students are able to post comments regarding the message at hand, either asking for additional information or leaving a comment of their own, where by all other individual, having access to the application, can view all interactions, and are ever notified that a new thread has just been added to the post.[8]-[9]

\subsection{Evaluation Instruments}

\subsubsection{Mid-term and Final examinations}

Student activity data were collected from two multiplechoice examinations each covering half of the course lesson. Examination items were both prepared by the lecturer and approved by course committee.

\subsubsection{Questionnaire}

After completed each lecture examination, students were asked to complete five point rating questions. Two some of them were included as probable predictors of the online study tool what has been used. The first question, asked students "the complicated lesson is hard to read in short message?" and was after with the choices of "I have no difficulty to read", (rating=5), "I have some difficulty to read" (rating=3), and "It is very difficult", (rating=1). The second, asked students "Do you response to any of your friend's activity regarding to the sent message?" and was after with the choices of "Yes every times" (rating=5), "Sometimes", (rating=3) and "I never look at it', (rating=1).

\subsubsection{Inventory of learning Processes (ILP)}

Students were asked to complete the ILP [7] to provide an indication of the quality of their study approaches. The ILP provides scores on four subscales: (1) Deep Processing, (2) Methodical Study, (3) Fact Retention, and (4) Elaborative Processing.

\section{Experimental}

In the first semester of 2013, one of Chiang Mai University computer network classes, which consisted of 45 undergraduate software engineering students, took part in this research. During class, students used the application via their mobile phone. They pasted relative messages and enquiries; from their actions alone, the students were interacting in class. With their phone in hand, these students were involved in the lesson content.

At the end of class, in class interactivity using the application ends. The after class use of the application is largely implemented by the lecturer who send short message repeat the recent in class lesson to the web application, and set time of 4 hours after class to post via the mobile application. Every day before 9am.-8pm., the short message lessons were divided into 5 messages for each 50 minutes in class lesson, having 4 hours intervals between each post. Moreover, students individually attended pre and post sub exams. Our finding from related questionnaires and interviews conducted yelled positive result from both students' lecturers.

The ILP is the evaluation tool which helps to indicate the progressive result of study group who use the application tools, and compare with the other group. 
Table 1 shows the ILP separated into four subscales: Deep Processing, Elaborative Processing, Fact Retention, and Methodical Study. The Deep Processing subscale measures the extent to which students focus on higherlevel concepts and critical evaluation of the information. The Elaborative Processing subscale measures a student's leaning to individually action the information, though such as self-participation. The Fact Retention subscale observes a student's tendency to learn facts and details. Lastly, the Methodical Study subscale measures how often a student studies. Also the ILP assess the study styles of students from an information processing perception. Using true or false, students specify if each of 62 statements represents the way they normally study and learn.

Table 1. The ILP subscale and example of question [7].

\begin{tabular}{|l|l|}
\hline \multicolumn{1}{|c|}{ Subscale } & \multicolumn{1}{c|}{ Example Question (Ture / Fault) } \\
\hline $\begin{array}{l}\text { The Deep } \\
\text { Processing }\end{array}$ & $\begin{array}{l}\text { "I find it difficult to handle questions } \\
\text { requiring comparison of different } \\
\text { concepts" }\end{array}$ \\
\hline $\begin{array}{l}\text { Elaborative } \\
\text { Processing }\end{array}$ & $\begin{array}{l}\text { "I learn new words or ideas by } \\
\text { visualizing a situation in which they } \\
\text { occur" }\end{array}$ \\
\hline Fact Retention & $\begin{array}{l}\text { "I am good at learning formulas, } \\
\text { names, and dates" }\end{array}$ \\
\hline $\begin{array}{l}\text { Methodical } \\
\text { Study }\end{array}$ & $\begin{array}{l}\text { "For the exam, I prepare a set of notes } \\
\text { integrating the information from all } \\
\text { sources in the course" }\end{array}$ \\
\hline
\end{tabular}

\section{Conclusion}

The result from student who done the ILP indicated that they were dramatically increased more attention the strategies related with Deep Processing and Elaborative Processing following the classroom teaching on the topic. Including processes slow by the Deep Processing and Elaborative Processing subscales is also more significant certain that these two subscales have presented important relations with academic achievement. Obviously, proves that education students about their specific online learning tools and new after-class study methods can help them gain more effective lesson understanding. And get better score in class, and use improved study abilities.

Table 2. Questionnaire shown result after semester.

\begin{tabular}{|l|c|c|}
\hline \multicolumn{1}{|c|}{ Question } & Agree & Disagree \\
\hline $\begin{array}{l}\text { The complicated lesson is hard } \\
\text { to read in short message }\end{array}$ & $36.7 \%$ & $63.3 \%$ \\
\hline
\end{tabular}

\begin{tabular}{|l|c|c|}
\hline $\begin{array}{l}\text { Sending message too often } \\
\text { bothering student }\end{array}$ & $21.1 \%$ & $78.9 \%$ \\
\hline $\begin{array}{l}\text { Response to every new message } \\
\text { when the notification has alarm }\end{array}$ & $30 \%$ & $70 \%$ \\
\hline $\begin{array}{l}\text { Response to any of friend's } \\
\text { activity regarding to the sent } \\
\text { message }\end{array}$ & $80.2 \%$ & $19.8 \%$ \\
\hline $\begin{array}{l}\text { Acquiring more understanding } \\
\text { of the lesson, what already have } \\
\text { studied in class }\end{array}$ & $76.4 \%$ & $23.6 \%$ \\
\hline $\begin{array}{l}\text { When student read message } \\
\text { because of incoming of new } \\
\text { message }\end{array}$ & $52.4 \%$ & $47.6 \%$ \\
\hline $\begin{array}{l}\text { Student read message following } \\
\text { friend click Impress }\end{array}$ & $68.7 \%$ & $31.3 \%$ \\
\hline
\end{tabular}

The mid-term examination shows benefit of using online tools, by increase class's score average, when comparing with previous semester. Main concern of the analysis was to define how the tools could influence student to read the message, and also inspiration other student to read it by the first student action. Table 2 Shown results of questionnaire from student after finished the research. Overall the positive result proved the origin concept of research in positive way. Student will have consideration on friend's activity more than incoming of the message, and their feels more comfortable to read short lesson message more often comparing with read very long sentence in study book.

\section{References}

1. Moore, M. G. Editorial: three types of interaction. The American Journal of Distance Education, 3(2), pp. 1-6, (1989)

2. Yacci, M. Interactivity demystified: a structural definition for distance education and intelligent computer-based instruction. Educational Technology, 40(4), 5-16,(2000)

3. Anderson, An updated and theoretical rationale for interaction. IT Forum. Retrieved 25 April, (2004)

4. Liu, T. -C., Wang, H. -Y., Liang, J. -K., Chan, T. -W., \& Yang, J. -C. Applying wireless technologies to a build highly interactive learning environment. In IEEE international workshop on wireless and mobile technologies in education, Va“xjo“, Sweden, (2002)

5. C.Markett, I. Arnedillo Sanchez, S. Weber, B. Tangney. Using short message service to encourage interactivity in the classroom. Science Direct Computer \& Education, (2006) 
6. Phudinan Singkhamfu, Patiphat Inkong, Chaithawat Suraphruk. Study Assistance by Social methodology application for mobile device, June 2014, conference on Global Trends in Academic Research, (2014)

7. Schmeck, R.Dillon, \& R. Schmeck (Eds.),. Learning styles of college students, Individual differences in cognition. (pp. 233-279). New York: Academic Press, (1983)

8. Haewoon Kwak, Changhyun Lee, Hosung Park, and Sue Moon. What is Twitter, a Social Network or a News Media? What is Twitter, a Social Network or a News Media, (2010)

9. Moira Burke, Cameron Marlow and Thomas Lento. Social Network Activity and Social Well-Being. CHI 2010: Social Media Users, (2010)

10. Bell, J. Doing your research project: A guide to firsttime researchers in education and social science (3rd ed.). Buckingham: Open University Press, (1999)

11. Ananny, M., Strohecker, C., \& Biddick, K. Shifting scales on common ground: developing personal expressions and public opinions. International Journal of Continuing Engineering Education and Life-Long Learning, 14(6), pp. 484-505, (2004)

12. Sharinaz Ismail, Noor Shahira Md Noor, Mohd Sharifuddin Ahmad. Social Network Analysis on Personal Knowledge Management. National Graduate Conference, University Tenaga Nasional, Malaysia, (2014) 